\title{
Development of a Learning Device Information System for Kindergartens
}

\author{
Rohita $^{1^{凶}}$, Nila Fitria ${ }^{1}$, Dody Haryadi², Radhiya Bustan ${ }^{3}$ \\ Pendidikan Guru Pendidikan Anak Usia Dini, Universitas Al Azhar Indonesia(1) \\ Teknik Informatika, Universitas Al Azhar Indonesia(2) \\ Psikologi, Universitas Al Azhar Indonesia(3) \\ DOI: $10.31004 /$ obsesi.v6i3.1378
}

\begin{abstract}
This study aimed to develop a learning device information system, abbreviated as SIPP, as a way of compiling multiple learning devices that include weekly learning implementation plans (RPPM), daily learning implementation plans (RPPH), and learning assessments. The system was built using unified modelling language (UML). The research was conducted for 3 years, where in year 1, data was collected using a survey followed by data processing, and determining the concept and model of SIPP using UML. In the second year, SIPP was developed by incorporating the content needed to develop learning tools, as well as system requirements, and in the third year, a virtual system trial was conducted. The results of the trial use of the system show that all the features in the SIPP which include the principal's account and the teacher's account can be used and utilized by teachers as well as principals. Based on these results, it can be concluded that the developed learning device information system can help teachers prepare lesson plans in kindergarten, as well as help principals monitor teacher performance related to the preparation of lesson plans.
\end{abstract}

Keyword: kindergarten teachers; learning device information system; early childhood education

\begin{abstract}
Abstrak
Penelitian ini bertujuan untuk mengembangkan sebuah system informasi yang dinamakan system informasi perangkat pembelajaran (SIPP) sebagai sebuah cara dalam menyusun perangkat pembelajaran yang mencakup rencana pelaksanaan pembelajaran mingguan (RPPM), rencana pelaksanaan pembelajaran harian (RPPH), dan penilaian pembelajaran. System dibuat dengan menggunakan Unified Modelling Language (UML). Penelitian dilakukan selama 3 tahun, dimana tahun 1 dilakukan pengumpulan data menggunakan survey dilanjutkan dengan pengolahan data, serta menentukan konsep dan model SIPP menggunakan UML. Tahun kedua dilakukan pengembangan SIPP dengan memasukkan konten-konten yang dibutuhkan untuk menyusun perangkat pembelajaran, serta kebutuhan sistem, dan di tahun ketiga dilakukan uji coba penggunaan sistem secara virtual. Hasil ujicoba penggunaan sistem menunjukkan bahwa seluruh fitur dalam SIPP yang mencakup akun kepala sekolah dan akun guru dapat digunakan dan dimanfaatkan oleh guru dan juga kepala sekolah. Berdasarkan hasil tersebut dapat disimpulkan bahwa sistem informasi perangkat pembelajaran yang dikembangkan dapat membantu guru menyusun rencana pembelajaran di TK, serta membantu kepala sekolah memantau kinerja guru terkait penyusunan perencanaan pembelajaran.
\end{abstract}

Kata kunci: guru taman kanak-kanak; sistem informasi perangkat pembelajaran; pendidikan anak usia dini

Copyright (c) 2021 Rohita,' et al.

$\triangle$ Corresponding author:

Email Address : rohita@uai.ac.id (Jakarta, Indoenesia)

Received 24 May 2021, Accepted 24 June 2021, Published 18 Agustus 2021 


\section{INTRODUCTION}

Every educator has an obligation to provide the best learning to support the growth and development of students, especially kindergarten-aged children. This requires learning devices that are ready to use, in accordance with learning objectives, and that can provide information on students' developmental achievements. Learning devices are equipment guide educators in carrying out the learning process in the classroom, laboratory, or outside the classroom (Prasetyo, 2011). Learning devices include lesson plans and assessment tools.

Planning is a systematic process of deciding what and how students should learn that forms part of a teacher's responsibilities. A learning plan is interpreted as a teacher's guide during the learning process (Oliva, 2005; Yusnida, Muslem, \& Manan, 2017) so that the learning scenario cannot be separated from the context that was prepared (Arifin, Nurtanto, Priatna, Kholifah, \& Fawaid, 2020). Additionally, lesson plans should be ready one week at the latest before the beginning of the academic year to make the necessary arrangements (Cicek \& Tok, 2014).

However, in the process of making learning devices, various obstacles can emerge. These obstacles stem more from administrative planning, namely the teacher's ability to plan learning programs and compile them into lesson plans (Gunawan, 2017; Noviawati, 2017). Preparing semester and annual learning programs that later translate into lesson plans is not easy (Fujii, 2016; Piper, Sitabkhan, Mejía, \& Betts, 2018). Among others, the difficulties in this process include the selection and application of core and basic competencies from the 2013 Pendidikan Anak Usia Dini (ECCE) curriculum in learning planning (Rohita, Fitria, \& Haryadi, 2018). Even though there are several obstacles in the learning planning process, kindergarten teachers still do it according to their abilities and understanding using computers. This has become a potential basis for thinking to help teachers prepare their learning devices in an easier and faster way by taking advantage of advances in technology and information systems.

Information systems aim to help humans carry out their daily life activities easier and faster. This can be seen in extant research results, including the application of the BOP PAUD (Operational Costs for Early Childhood Care Education) accountability system, which makes it easier to make BOP PAUD accountability reports (Machmuddah \& Suhartono, 2019). The easy use of information systems also occurs in the fields of accounting, management, and elementary schools and kindergartens (Koloay, Morasa, \& Elim, 2014; Meliana, Julianto, \& Hafidz, 2020; Nugroho, 2015; Parsaorantua, Pasoreh, \& Rondonuwu, 2017; Prananda \& Datu, 2016). Likewise with the time needed to complete a job, Kaleb, Lengkong and Taroreh stated that time efficiency can be felt when compared to before the implementation of the management information system at KPP Pratama Manado (Kaleb, Lengkong, \& Taroreh, 2019).

The ability to use technology and information systems should be improved, however, especially now in the so-called industrial revolution 4.0 (Rohita, 2020). Afrianto writes, "Today's educator is obliged to make self-adaptation and certain changes to successfully utilize all the potential benefits brought by the IR 4.0 era." (Afrianto, 2018) In this study, the many benefits of using an information system were applied in kindergarten education by developing a system using unified modelling language (UML). UML is a language that can be used to describe things (Wazlawick \& Sidnei, 2014) and is intended for the specification, visualization, development, and documentation of software systems. Through UML, models can be made of all types of software applications that run on any hardware, operating system, or network and are written in any programming language (Abdurohman, Kuspriyanto, Sutikno, \& Sasongko, 2010). There are many studies related to the use of UML (Ansari, Hasan, \& Khan, 2018; Jurgelaitis, Ceponiene, \& Drungilas, 2018; Kornelis \& Ock, 2014; Luzi, Pecoraro, \& Tamburis, 2016; Terolli \& Hakrama, 2014).These include topics in the world of education(Ansari, 2010), but an information system that uses UML in kindergarten education specifically has not yet emerged. 


\section{METHODOLOGY}

This research is a development study that was carried out in stages. The first year determines the SIPP concept and model using UML, the second year develops SIPP, and the third year measures the effectiveness and efficiency of the SIPP being developed. The problem this study solved was a means of arranging effective and efficient learning devices in the form of an information system. To solve this problem, a requirement analysis and determination of learning device preparation was carried out in the first year of this research; the results of the first year were the creation of a learning device information system. In the second year, learning device content was developed according to teachers' needs while preparing RPPM (weekly learning implementation plans), RPPH (daily learning implementation plans), and learning outcome assessments. In the third year, the preparation of learning devices that use information systems was implemented and evaluated. The detailed steps of the first-year research activities are (1) Requirement Analysis, (2) Design, (3) Construction, (4) Testing and Implementation, and (5) Documentation.

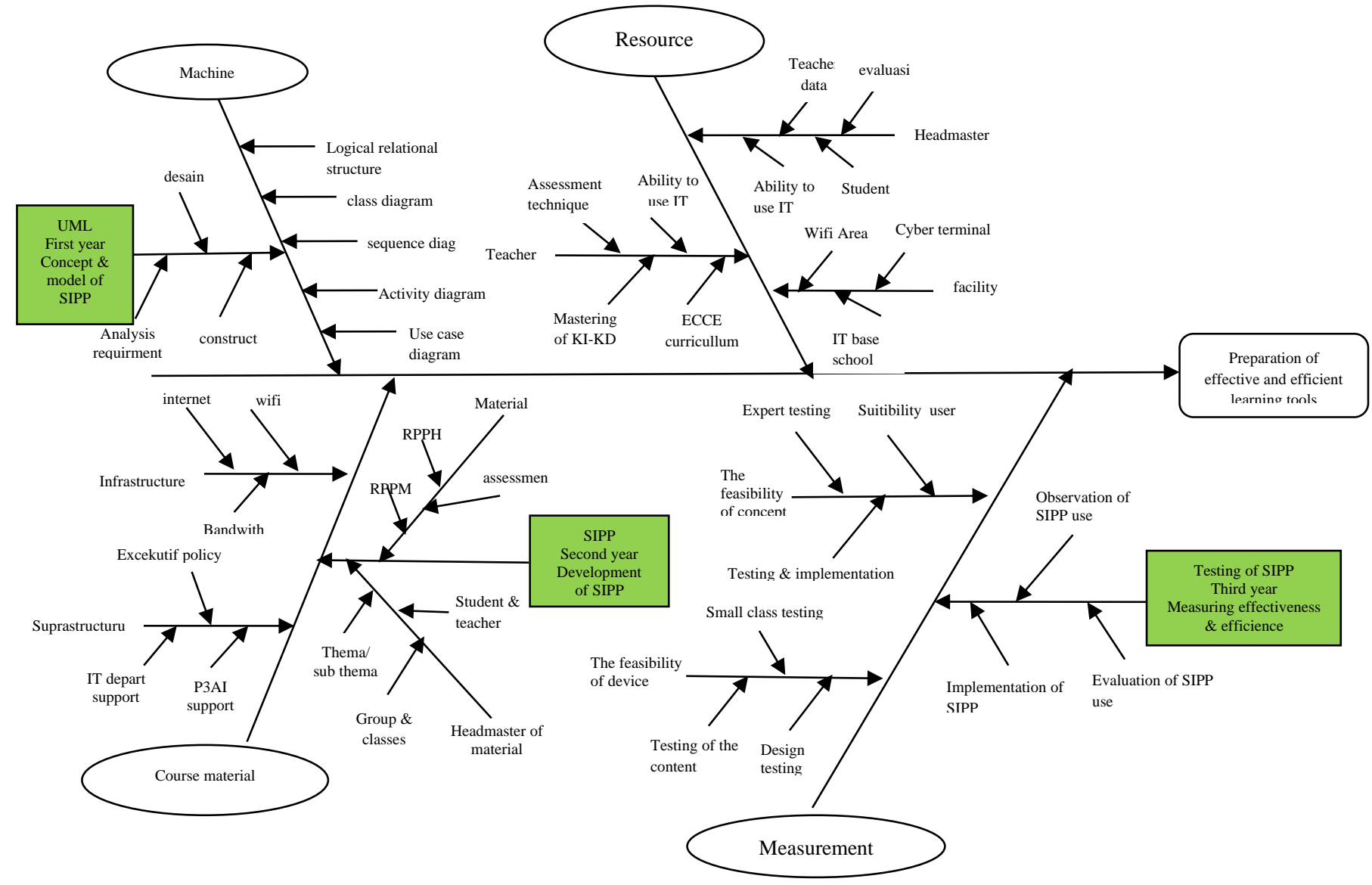

Figure 1. fishbone of development of SIPP

\section{RESULTS AND DISCUSSION}

The following sections show some of the steps taken in compiling the learning device information system.

\section{Requirement Analysis}

At this stage, the data collection process, elicitation process, requirement analysis, and making of requirement specifications were carried out. Based on the analysis results, the 
information obtained indicatedthattwo accounts were necessary: one for principals and one for teachers. In the principal account, there is a templatetofill in learning themes, sub-themes, teacher data, and student data, as well as study groups and class divisions. For the teacher account, there is a template to arrange the learning devices. The data filled in throughthe principal template are required for teachers to be able to fill in the templatein their account. The results of the requirement analysis yieldeda process flow chart, elicitation results, and software requirement documents, as shown in Figure 2.

Based on the results of the needs analysis, it is known the contents and work orders that need to be included in the SIPP. Figure 3 shows the content contained in the system as well as the work order for each content.

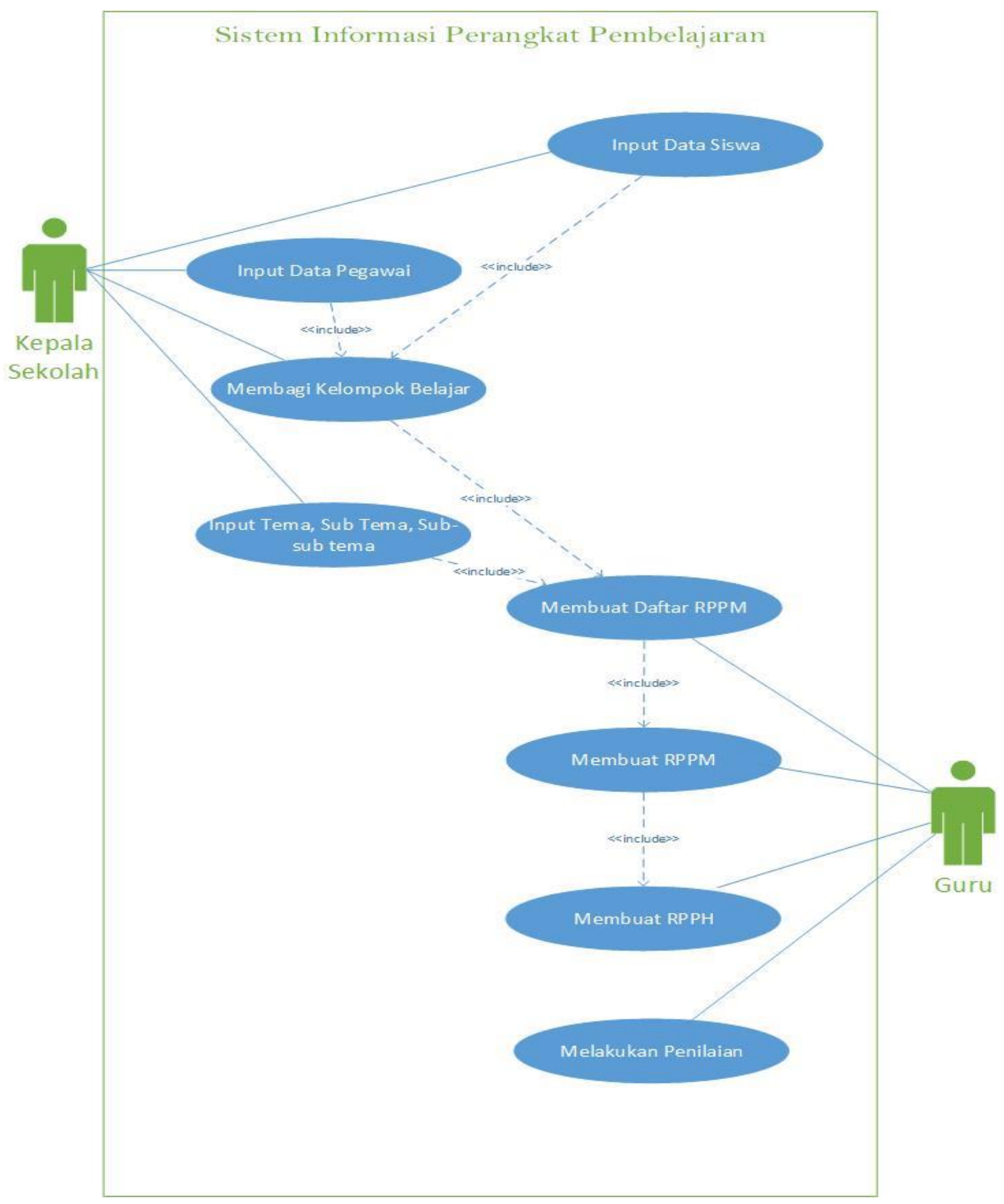

Figure 2. SIPP of use case diagram 


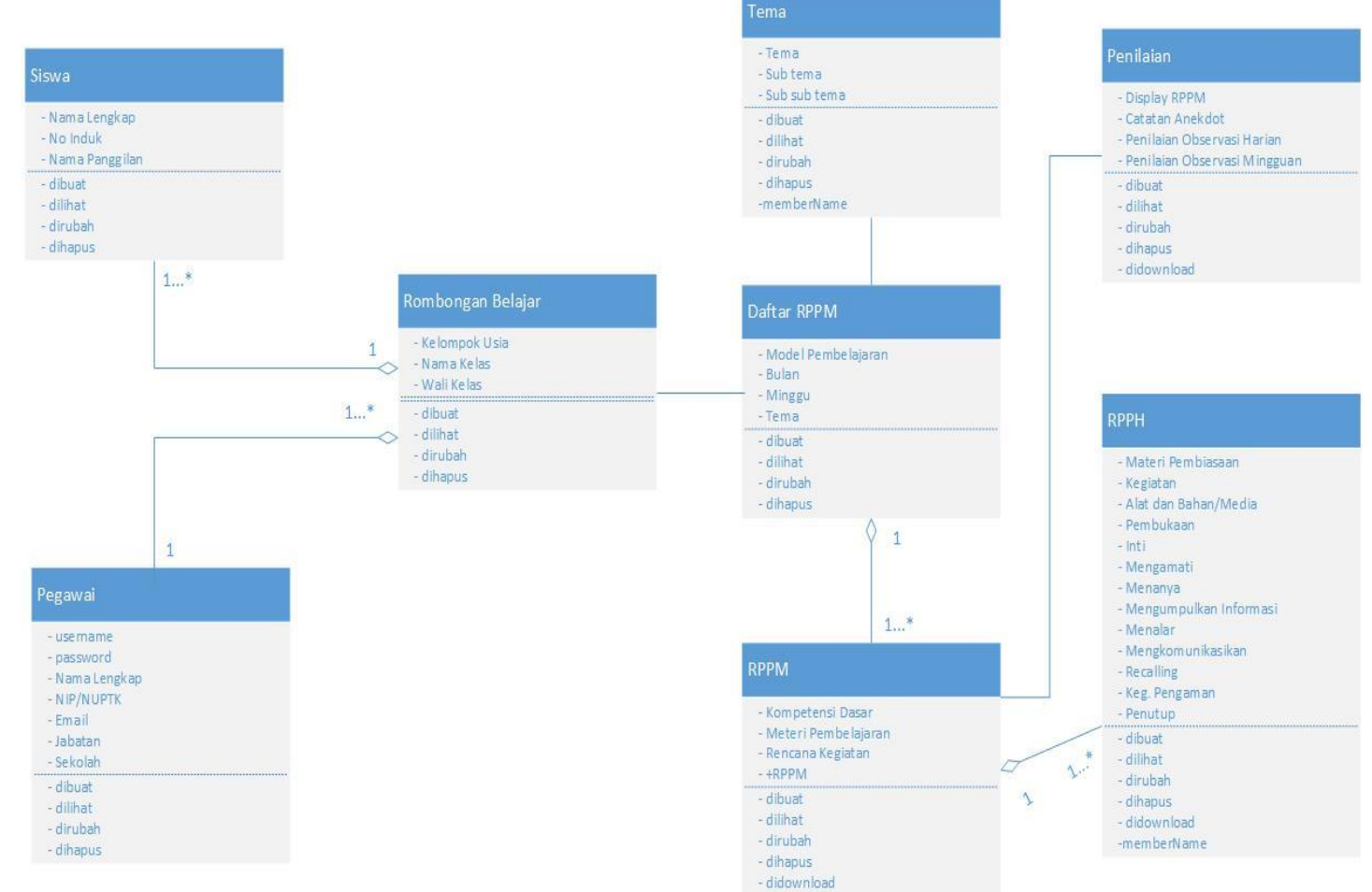

Figure 3. SIPP of Unified Modelling Language (UML) Case Diagram

\section{Product Description}

The resulting information system is divided into two types: 1) information systems accessed by teachers, and 2) information systems accessed by principals. Both systems are housed in cloud servers. However, two servers are used in general, which are the cloud server that contains the information system itself and an internal server that contains data related to the needs of learning device preparation, such as teachers, students, sub-theme themes, core competencies-basic competencies, weekly and daily planning, and assessment. Both servers communicate and synchronize their data.

The main purpose of making SIPP is to assist teachers in preparing weekly lesson plans and daily lesson plans, assessing learning outcomes in the form of observation sheets and anecdotal notes, as well as making reports on child development in the form of report cards, as well as inserting pictures to support the development reports of the child. Although the main users of SIPP are teachers, the involvement of principals is also not small. The principal has the role of inputting the main data sources in the form of employee data, student data, institutional data, determining study groups, including inputting extracurricular activities and themes. Through the principal's account contained in the SIPP, the principal can also view teachers' pre learning activities in compiling the RPPM and RPPH as well as children's development achievements in the form of assessments and report cards. To know the process, the principal can access directly through the principal's account without having to wait for the teacher to hand over the learning tools. In this case the principal can also assess the teacher's performance in readiness to carry out learning to the preparation of reports on child development. The results of the monitoring can be given by the principal to the teacher to be able to remind or motivate and even give appreciation to teachers who are orderly in learning administration.

\section{Product Function}

There are three product functions in SIPP, namely information systems, content management, and user characteristics.

\section{Information System}


In this information system is divided into 3 parts, namely: 1). Overview. There is a main menu consisting of: study groups, students, employees, schools, extracurriculars, and themes. This section is later used by the principal; 2). Process: a). principal login to the portal, b). fill in school data, c). fill in student data, d). Fill in employee data, including creating a username and password for teachers, e). filling out extracurricular data, f). Fill in the subthemes, and e). $\log$ out of the portal. 3). Output: institutional identity, employee data, student data, study groups, extracurriculars, and themes. The whole process is carried out after the principal logs into the sipp-tk.com portal by entering the username and password provided by the SIPP maker (author this paper).

\section{Content Management}

In this content management there are also 3 parts, namely: 1) Overview: RPPM and view students, used by teachers, 2) Process: a). The teacher logs into the portal, b). Prepare RPPM: choose time, themes- subthemes, core competence - base competence (CC-BC), fill out activity plans, and fill in learning materials, c). Prepare RPPH: select activity plans, learning materials, learning models, fill in opening activities, core activities, closing activities, d). Input values: observational assessments, anecdotal notes, and e). make report cards: : fill out a narrative on six development aspectsand upload photos. 3). Output: RPPM, RPPH, weekly assessment, daily assessment, anecdotal notes, and report cards. The whole process is carried out after the teacher logs into the sipp-tk.com portal by entering the username and password created by the principal.

\section{User Characteristics}

There are two types of users for this application, which are principals and teachers. The role of the principal is to 1) enter student data, 2) enter teacher data, 3) create themessubthemes for one school year, which is divided into 2 semesters, and 4) determine each class's homeroom teacher and study group. The teacher's role, meanwhile, is to 1) prepare RPPM, 2) prepare RPPH, 3) conduct assessments, and 4) make report cards.

\section{System Design}

SIPP was designed using PHP programming language with CodeIgniter. Meanwhile, the database development uses MySQL, which operates the database server. The interface design was designed withCSS. Thedatabase design also reliedonan entity relationship diagram, data flow diagram, and flowchart. PHP and MySQL allow users to access SIPP anywhere, anytime, and by using any technology, such as laptops, and smartphones. After the information system was fully constructed, the next steps were testing and implementing it. At this stage, the researchers tested the application on several students from the early childhood education teacher education study program who acted as teachers. The application testing revealed several differences or errors in the information system that werethen revised.

\section{Display of Product Result (SIPP)}

The result of this research is a UML-based learning device arrangement system called SIPP. To create a learning process that supports teachers as planners and implementers of learning andprincipals as institutional managers, this information system is built for use according to the number of classes that educators can manage, as illustrated in Figure 4. 


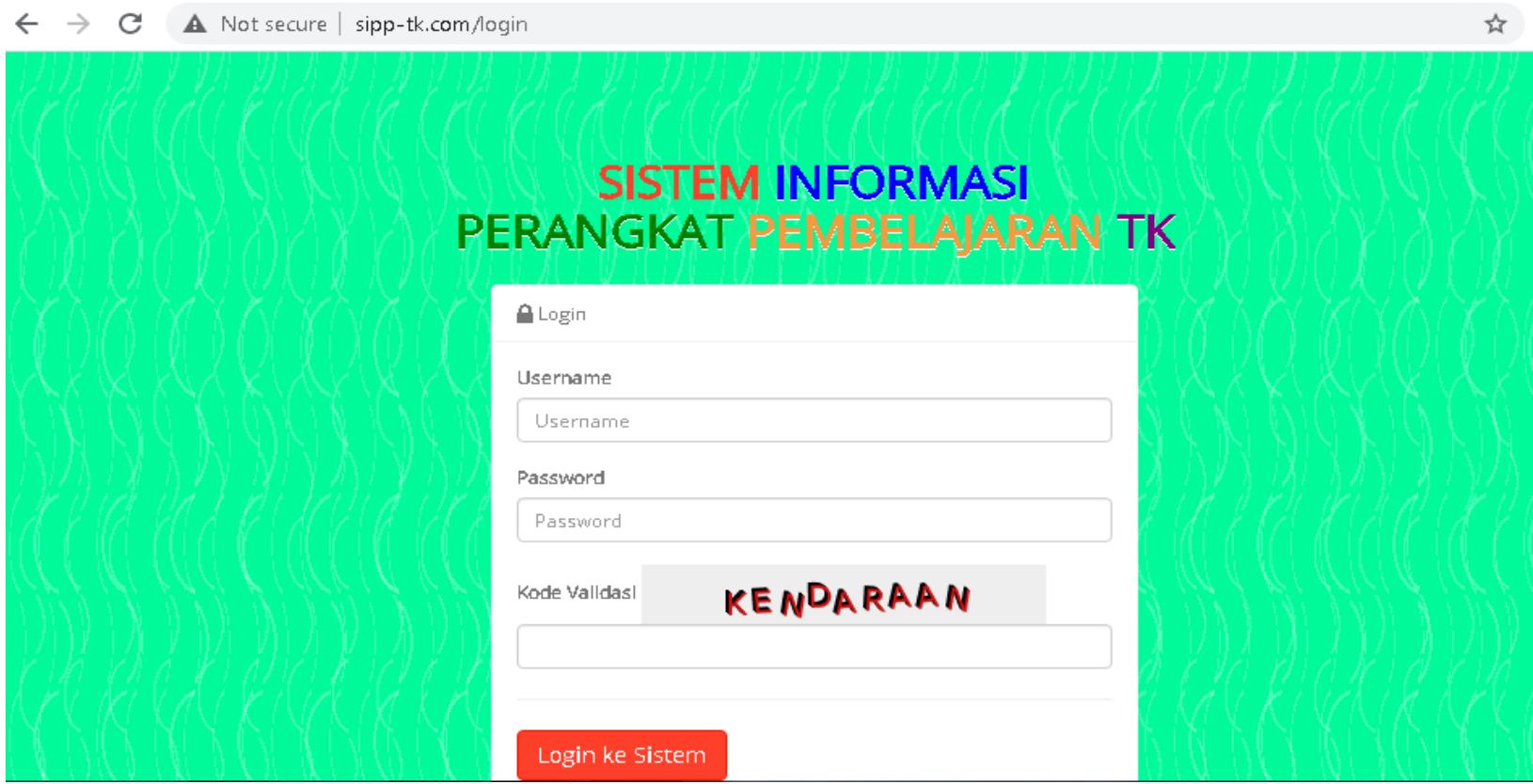

Figure 4. SIPP login page

Figure 5 shows each menu item in the principal account, as follows: 1) Profiles, to fill inbriefschool principal data, 2) Study group, to fill in the homeroom teacher, number of students, and their names, 3) Students, to fill in the students' identification information, 4) Employees, to fill in the data of the institution's employees who are given access to SIPP, 5) School, containing the school's address and logo, and 6) Extracurricular, to fill in the extracurricular activities provided at the institution. As for Figure 6, there are the menu options 1) Profiles, to fill in brief teacher data, 2) RPPM, to fill in lesson planning, and 3) See students, to find the names and number of students who are the teachers' responsibility. The informationfilled in through the principal menu is connected to the teacher account to use when preparing the learning devices.

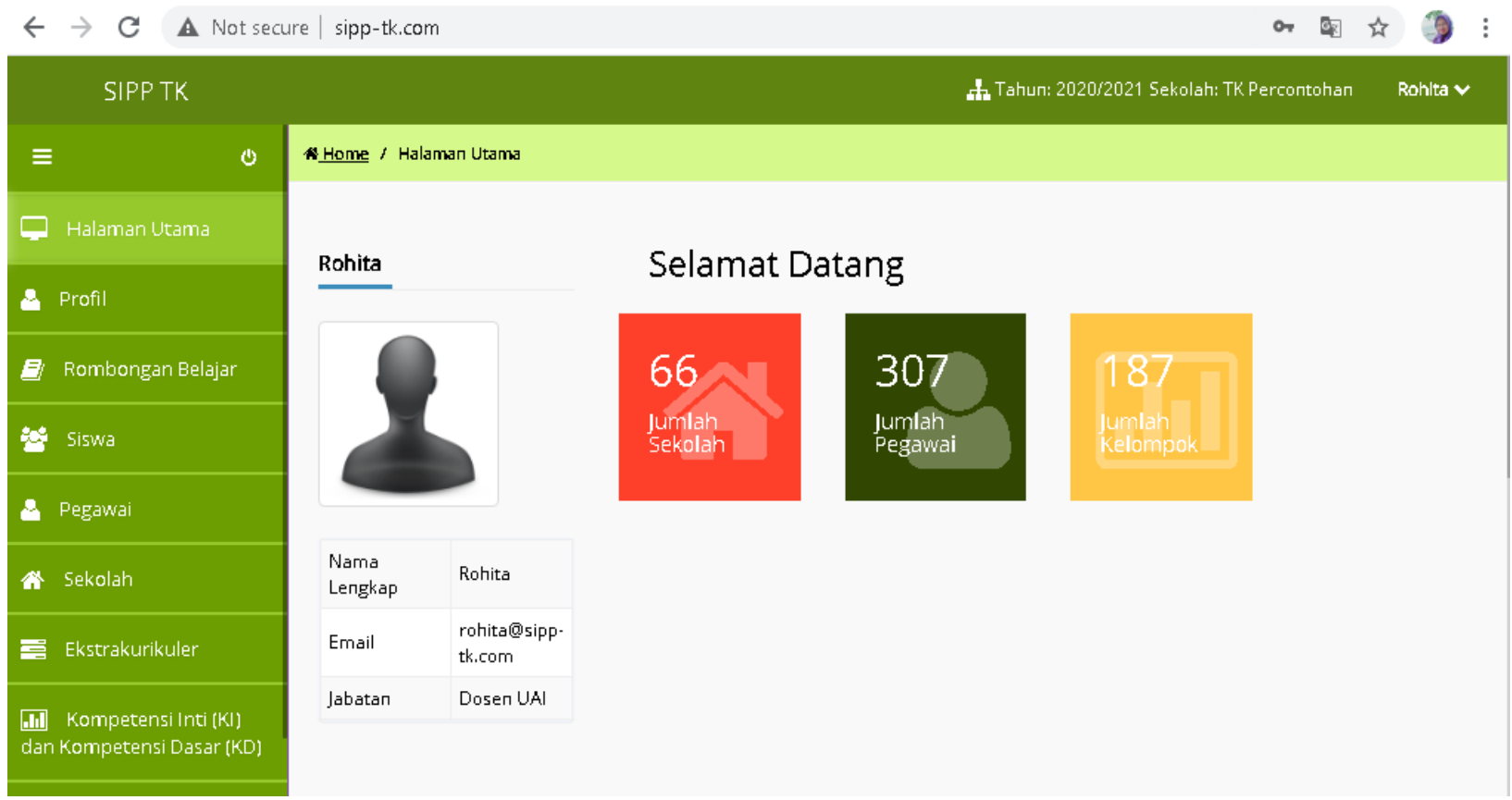

Figure 5. SIPP principal main menu 


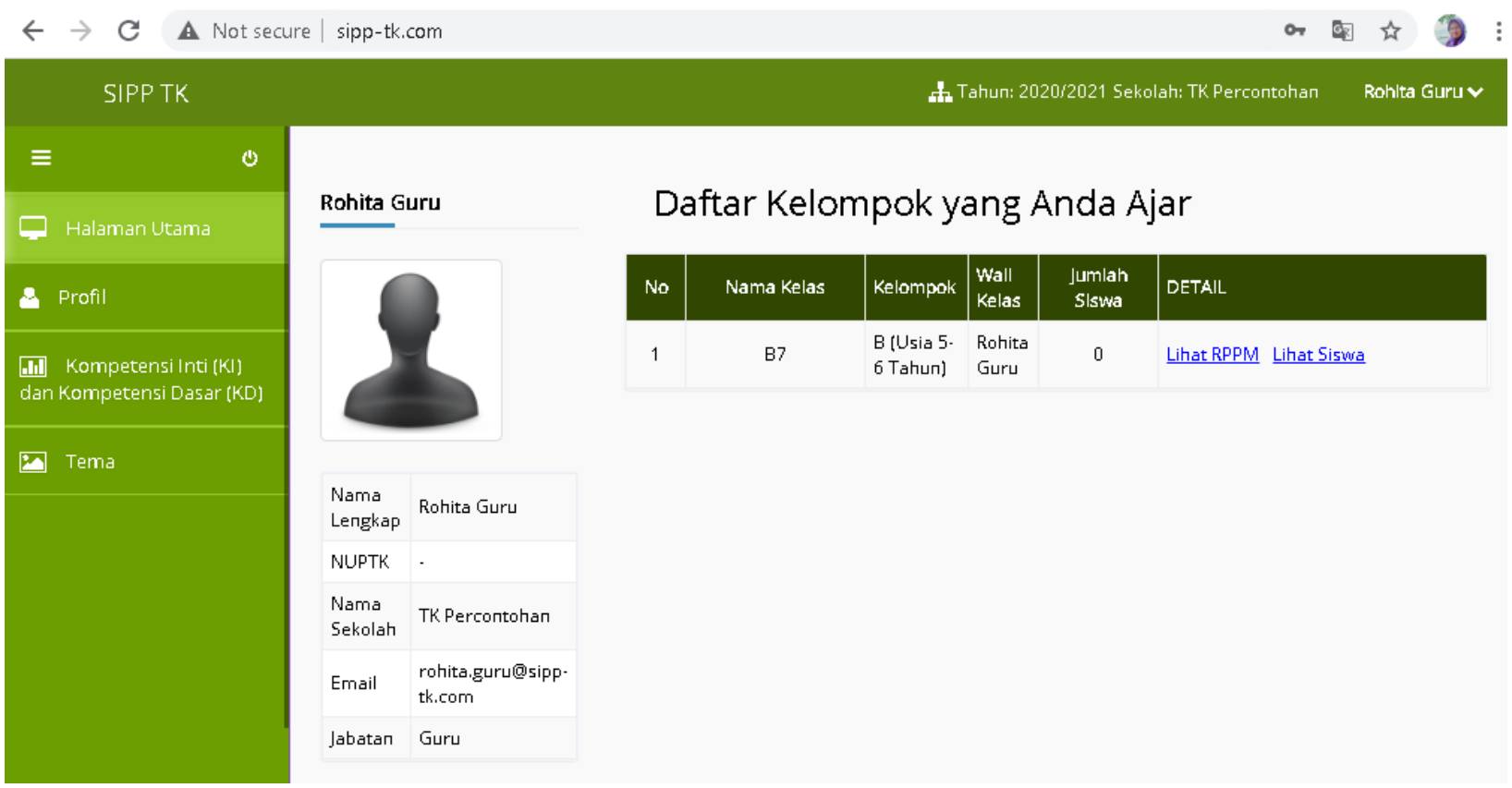

Figure 6. SIPP teacher maintemplate

Figure 7 depicts a data add template in the RPPM arrangement management, which determines the time to implement learning, select themes and sub-themes, choose learning materials, and plan activities.

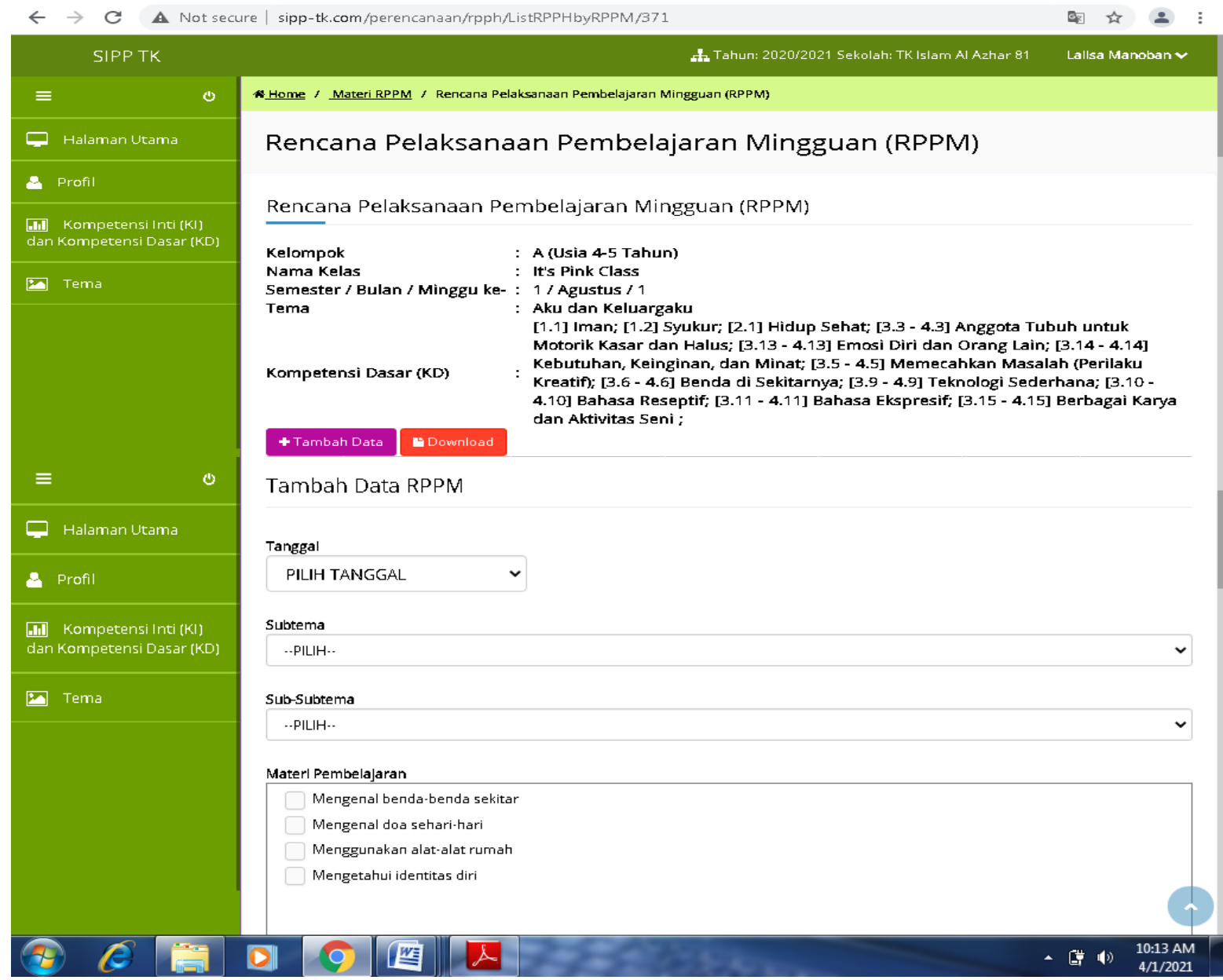

Figure 7. RPPM arrangement management 
As seen in Figure 8, teachers can arrange their RPPH as well in the space provided by clicking on the edit data section. Several columns, such as those for the learning model, materials, and activity plans, are fixed after choosing these fields when filling in the RPPM. The content that can be filled in is material for habituation, tools and materials/media, and opening, core, and closing activities. Under core activities, teachers can fill in a scientific approach that includes observing, asking questions, gathering information, reasoning, and communicating.

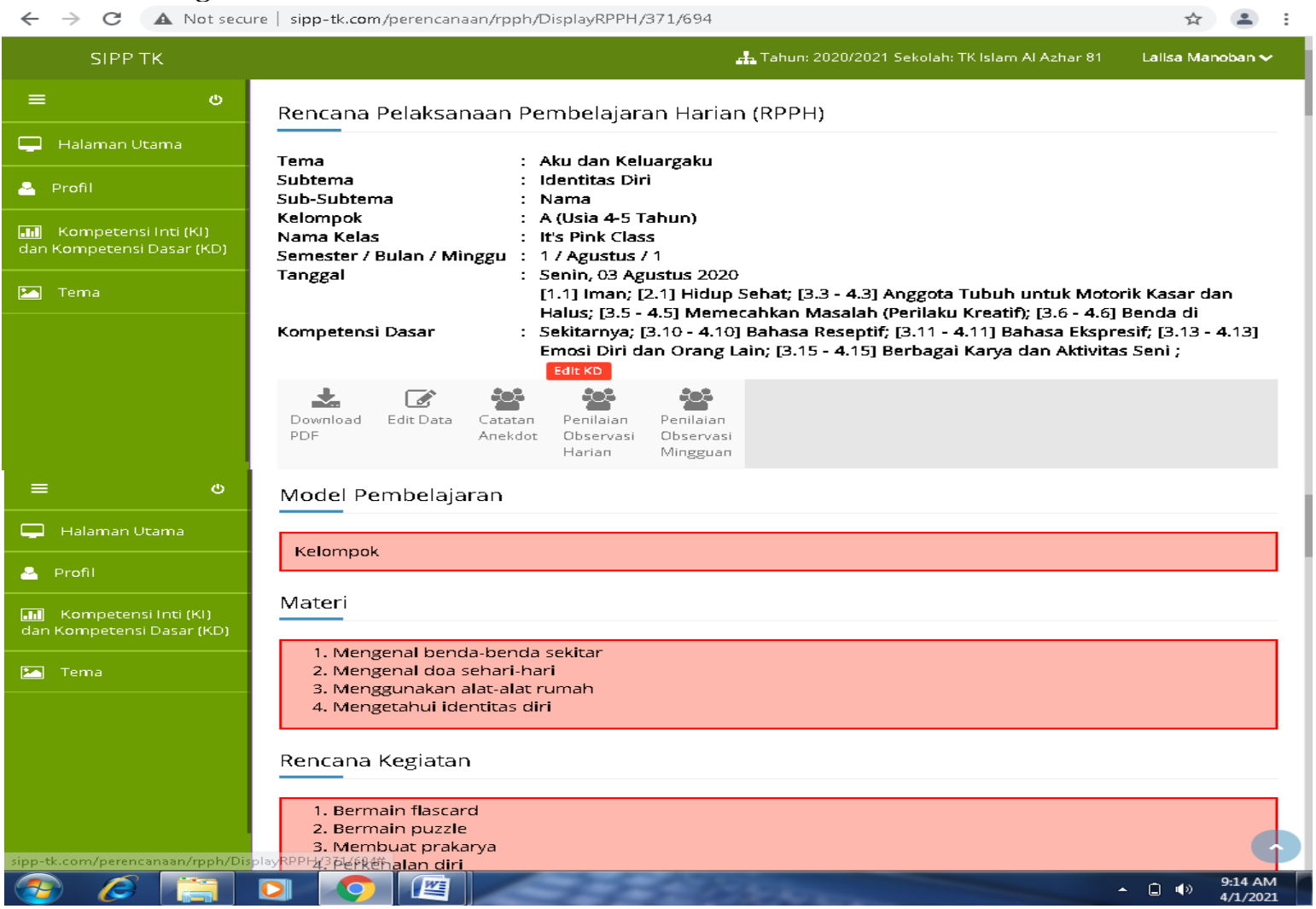

Figure 8. RPPH arrangement management

$\leftarrow \rightarrow$ C A Not secure $\mid$ sipp-tk.com/penilaian/kelas/CatatanAnekdot/371/694

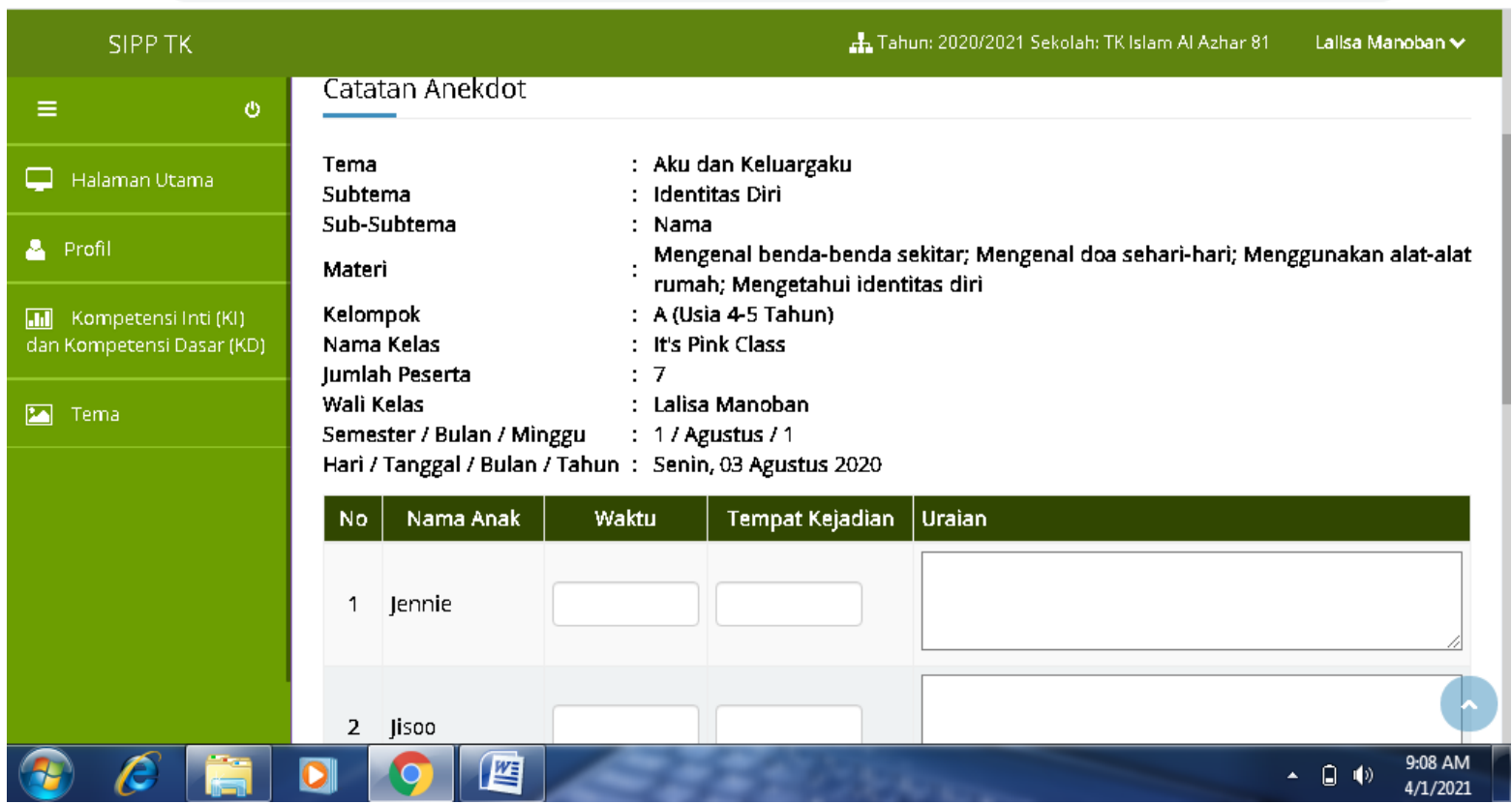

Figure 9. Assessment managing of anecdotal notes 
Figure 9 shows an anecdotal note format image as one of the assessment tools used in kindergarten classes. Anecdotal notes are used to record various unusual events that children experience or do at certain times and places.

Figure 10 is a daily observation assessment form in which an activity is listed per date, theme, sub-theme, sub-sub-theme, material, class name, group, number of participants, and homeroom teacher. This section also lists the development program and code of basic competence (BC), along with the students' names and achievements asdetermined with underdeveloped (BB [Belum Berkembang]), starting to develop (MB [Mulai Berkembang]), developing as expected (BSH [Berkembang Sesuai Harapan]), and developing very well (BSB [Berkembang Sangat Baik]) assessment criteria.

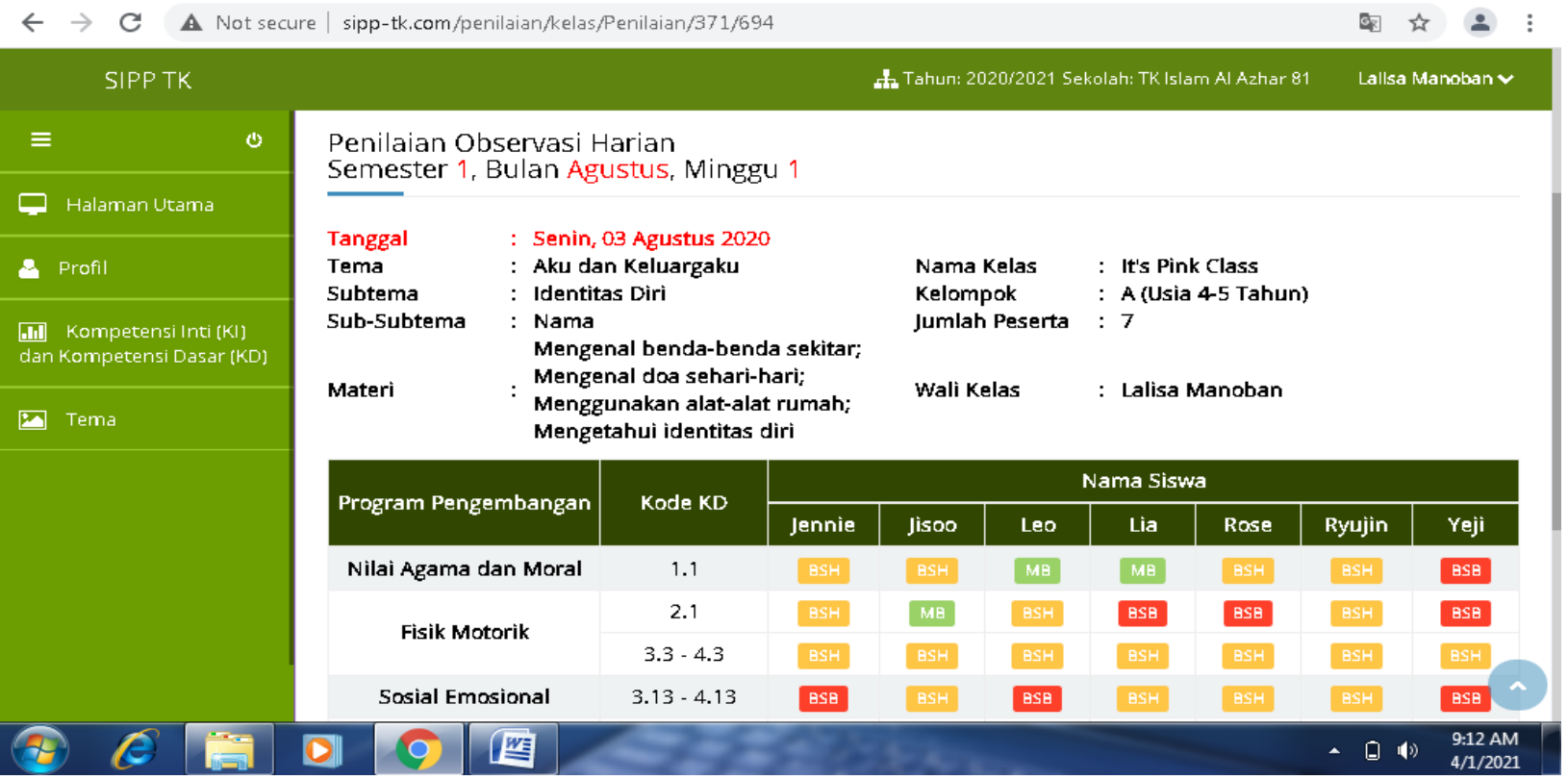

Figure 10. Assessment managing of daily assessments

The main concern in this learning device information system, are the principal and teacher accounts. Accounts for principals function to input data in general, namely student data, teacher data, as well as data on themes and sub-themes. Student data is inputted at the beginning of each academic year and the theme and sub-themes are inputted at the beginning of every odd and even semester. This division is intended to make it clear the themes and subthemes used in each semester. The theme and sub-theme input is placed on the principal's account with the aim of avoiding any changes or replacement of themes and sub-themes, which are carried out by the teacher either intentionally or unintentionally when preparing lesson plans. Regarding teacher data input, it can be done at any time after the person concerned officially becomes an employee at the institution.

The former functions to input general data, namely that on students, teachers, and themes and sub-themes. These data become "entry points" for teachers to carry out activities to prepare their lesson plans. Student and teacher data are entered as the basis for grouping students into classes and determining homeroom teachers in aspecific class. The principal can determine two teachers in one class with a certain number of students. The task of inputting these data can be carried out by anadministrator if the principal gives the necessary authority; this also applies to themes and sub-themes. However, these data need to be input from aprincipal account to avoid changes in themes and sub-themes, which teachers can do either intentionally or unintentionally

The student data and teacher data entered are the basis for grouping students in classes and determining the homeroom teacher in the specified class. The principal can determine 2 teachers in one class with a certain number of students. Meanwhile, the existence of themes 
and sub-themes on the principal's account becomes the "entrance" for teachers to be able to carry out activities in preparing lesson plans. That is, if the themes and sub-themes have not been entered into the principal's account, the teacher has not been able to develop a lesson plan. The task of inputting these data can be done by the admin if the principal gives his authority to the admin, by providing a username and password.

In the teacher account, teachers can use the themes and sub-themes input through the principal account to prepare lesson plans. Selecting sub-themes starts with the preparation of an RPPM. Then, automatically chosen themes and sub-themes are included in the RPPH's information, assessment form, and report cards. If atheme and sub-theme have been selected, teachers can complete the RPPM preparation by filling in all the sections. In preparingthe RPPM, teachers must determine the learning model, core competencies, and basic competencies from every aspect of development, fill in the learning materials, and create the activity plan. After all the sections are complete, teachers can then fill in the RPPH. In this section, the teacher must include various habituation activities and fill in the opening and core activities, as well as complete the part concerningthe scientific approach, fill in the closing activities, and finalizethe evaluation section. Through the RPPH form, teachers can also choose the assessment technique to use. There are two ways to determine the development and learning assessment model. In addition to using themes and sub-themes, teachers can conduct assessments of technical classes, namely anecdotal notes and observations. The scores entered in the daily observation assessment areautomatically included in the weekly observation assessment so teachers can see each child'sachievements. The assessment is also entered automatically into the children's report cards. The assessment criteria used are underdeveloped (BB), starting to develop (MB), developing as expected (BSH), and developing very well (BSB). Anecdotal notes are used to assess any events that are unusual or different from what the child usually does.

To confirm its function, 15 teachers and 15 school principals from 15 kindergarten institutions located in the Kebayoran Baru District, South Jakarta used SIPP. The respondents were determined by the head of the Kindergarten Teachers' Association, who considered the readiness of technology and human resource capabilities in each institution. In addition, the group learning model is also one of the criteria determined for selecting respondents, because SIPP has content that facilitates group learning models in the preparation of the RPPH. After the system was introduced and the respondents thoroughly trained in its use, respondents were given a questionnaire consisting of 3 parts, namely: 1). the process of filling out the SIPP to find out the function of the system, both the functions contained in the teacher's account and the principal's account; 2). the benefits of SIPP to find out the benefits that can be felt by both teachers and school principals; and 3). SIPP display to find out the attractiveness of the display itself as well as views related to the data needed in the preparation of learning tools. The information obtained based on the answers given by the respondents is presented in graphic form as follows.

SIPP poses an alternative means for teachers to carry out their duties as learning planners and child development report makers. The lack of time required to arrange learning device tools allows SIPP users to improve their performance. (Machmud, 2013) writes that information system management plays a positive role in increasing employee work effectiveness. Utilizing SIPP will also improve teachers' performance, especially when making decisions regarding child development. Through SIPP, school principals do not need to wait up to one semester to learn about children's developmental achievements, as the daily assessments entered by teachers into the system automatically appear in the weekly assessment as a recap of the children's average scores, which is then automatically input into the report card page. This certainly saves time and effort because, conventionally, teachers are busy each semester with filling in grades on handwritten report cards.

Using SIPP can save time and effort, but it can also save money. This program can further help users avoid mistakes and reduce the paper consumption that is usually required 
when using Microsoft Word or Excel and printing report cards. As Aslan dan Cinar (2018), argue if almost all kinds of sectors use information systems in daily operations to become highquality or low-cost producer. Through SIPP, report cards that already contain weekly grade recaps only need to be downloaded and then sent to parents. Principals can also SIPP as well to evaluate teacher performance. They can see firsthand the RPPM, RPPH, and assessments the teachers made without having to ask or wait for the data; as Sujoko argues, the benefits of information and communication technology ICT in education are the evaluation of student performance (or ,in this case, teacher performance) (Sujoko, 2013) and increasing employee productivity (Aslan \& Cinar, 2018). In addition to increasing efficiency, effectiveness, and teacher performance evaluation tools, SIPP can improve the quality and progress of the institutions in which it is used. Aswati et al. see using information systems in higher education for internal activities as a factor in higher education's success and progress (Aswati, Mulyani, Siagian, \& Syah, 2015).

Table 1. Principal account

\begin{tabular}{|c|c|c|c|c|c|}
\hline Component & Very difficult & Difficult & Quite & Easy & Very Easy \\
\hline input of themes and sub-themes & & $4.55 \%$ & $41 \%$ & $36.4 \%$ & $18.2 \%$ \\
\hline input of study groups and class divisions & & $4.55 \%$ & 415 & $32 \%$ & $23 \%$ \\
\hline input of student and educator data & & $9.1 \%$ & 415 & $36.4 \%$ & $13.6 \%$ \\
\hline
\end{tabular}

Tabel 2. Teacher account

\begin{tabular}{|c|c|c|c|c|c|}
\hline Component & Very difficult & Difficult & Quite & Easy & Very Easy \\
\hline filling in of RPPM & & & $27.3 \%$ & $50 \%$ & $22.7 \%$ \\
\hline filling in of RPPH & & & $27.3 \%$ & $45.5 \%$ & $27.3 \%$ \\
\hline filling in of anecdotal notes & & & $31.8 \%$ & $45.5 \%$ & $22.7 \%$ \\
\hline filling in of daily assessments & & & $31.8 \%$ & $41 \%$ & $27.2 \%$ \\
\hline filling in of weekly assessments & & & $36.4 \%$ & $31.8 \%$ & $31.8 \%$ \\
\hline filling in of report cards & & & $36.3 \%$ & $41 \%$ & $22.7 \%$ \\
\hline
\end{tabular}

Table 3. SIPP'S benefits for Principal

\begin{tabular}{|c|c|c|c|c|c|}
\hline Component & $\begin{array}{l}\text { Strongly } \\
\text { not agree }\end{array}$ & $\begin{array}{c}\text { Not } \\
\text { agree }\end{array}$ & doubt & agree & $\begin{array}{c}\text { Strongly } \\
\text { agree }\end{array}$ \\
\hline arrange class management & & & $27.3 \%$ & $36.4 \%$ & $36.4 \%$ \\
\hline $\begin{array}{l}\text { monitor teachers' teaching readiness (i.e., } \\
\text { performance) }\end{array}$ & & & $13.6 \%$ & $50 \%$ & $36.4 \%$ \\
\hline evaluate teachers' teaching readiness & & & $9.1 \%$ & $59.1 \%$ & $31.8 \%$ \\
\hline
\end{tabular}

Table 4. SIPP'S benefits for Teacher

\begin{tabular}{|c|c|c|c|c|c|}
\hline Component & $\begin{array}{c}\text { very } \\
\text { unhelpful }\end{array}$ & $\begin{array}{c}\text { unhelp } \\
\text { ful }\end{array}$ & Quite & helpful & $\begin{array}{c}\text { very } \\
\text { helpful }\end{array}$ \\
\hline arrange RPPM and RPPH & & & $13.6 \%$ & $36.4 \%$ & $50 \%$ \\
\hline fill in assessments and report cards & & & $18.1 \%$ & $36.4 \%$ & $45.5 \%$ \\
\hline
\end{tabular}

Table 5. SIPP Display

\begin{tabular}{lccccc}
\hline \multicolumn{1}{c}{ Component } & Very unattractive & Not attractive & Quite & attractive & very attractive \\
\hline display & & & $31.8 \%$ & $45.5 \%$ & $22.7 \%$ \\
& very uninformative & uninformative & Quite & Informative & Very Informative \\
& & $4.55 \%$ & $22.7 \%$ & $36.4 \%$ & $36.4 \%$ \\
content & Very inapproriate & Inappropriate & Quite & Appropriate & very appropriate \\
& & & $18.1 \%$ & $45.5 \%$ & $36.4 \%$ \\
content based & & & & \\
on learning & & & & & \\
requirements & & & & & \\
\hline
\end{tabular}




\section{CONCLUSION}

This learning devices information system for kindergarten, abbreviated as SIPP, is designed to assist kindergarten teachers in preparing lesson plans, make it easier to conduct assessments, and report assessmentresults in the form of report cards. Core and basic competencies, themes and sub-themes, and assessment criteria consisting of underdeveloped (BB), starting to develop (MB), developing as expected (BSH), and developing very well (BSB), onlyneed to be listed andthen are automatically integrated intothe report card content. Principals also feel the benefits of using SIPP, especially when observing teacher performance in a series of learning processes, such as planning and conducting assessments and reporting children's development. School principals no longer need to wait for a hard copy of what the teachers made, but can see it directly with SIPP access through aschool principal account. Kindergarten institutions who are interested in using SIPP to develop learning tools can contact the author via email: rohita@uai.ac.id.

\section{ACKNOWLEDGEMENTS}

We would like to express our gratitude to the Ministry of Researchand Technology/National Innovative Research Agency for the funding they gavefor the higher education superior applied research schemes throughout 2018-2020. We also thank the Institute for Research and Community Service at the University of Al Azhar Indonesia for all the support and facilities provided to us.

\section{REFERENCES}

Abdurohman, M., Kuspriyanto, Sutikno, S., \& Sasongko, A. (2010). Perancangan Aturan Transformasi UML-Systemc dalam Perancangan Embedded System. Jurnal Ilmu Komputer dan Informasi, 3(2), 91-97. https://doi.org/10.21609/jiki.v3i2

Afrianto. (2018). Being a Professional Teacher in the Era of Industrial Revolution 4 . 0 : Opportunities , Challenges and Strategies for Innovative Classroom Practices. Eltar Conference, 2(1), 1-13.

Ansari, G. A. (2010). Domain-Oriented Modeling of Indian Education System Through UML DomainOriented Modeling of Indian Education System Through UML. The IUP Journal of Systems Management, 8(3), 37-42.

Ansari, G. A., Hasan, M. M., \& Khan, M. N. (2018). " UML General Framework for IT Educational Sector : A Critical Approach for UML General Framework for IT Educational Sector: A Critical Approach for Precise Communication \& Analysis. International Journal of Computer Science and Network Security, 18(6), 79-86.

Arifin, Z., Nurtanto, M., Priatna, A., Kholifah, N., \& Fawaid, M. (2020). Technology Andragogy Work Content Knowledge Model as a New Framework in Vocational Education : Revised Technology Pedagogy Content Knowledge Model. Technology, Education, Management Journal, 9(2), 786791. https:// doi.org/10.18421/TEM92-48

Arifin, Z., Nurtanto, M., Warju, W., Rabiman, R., \& Kholifah, N. (2020). The TAWOCK conceptual model at content knowledge for professional teaching in vocational education. International Journal of Evaluation and Research in Education, 9(3), 697-703. https://doi.org/10.11591/ijere.v9i3.20561

Aslan, I., \& Cinar, O. (2018). The impact of management information systems' effectiveness on innovation. (G. E. ÇiFTÇİ, Ed.). Turkey: Iksad.

Aswati, S., Mulyani, N., Siagian, Y., \& Syah, A. Z. (2015). Peranan Sistem Informasi dalam Perguruan Tinggi. Jurnal Teknologi dan Sistem Informasi, 1(2), 79-86.

Cicek, V., \& Tok, H. (2014). Effective Use of Lesson Plans to Enhance Education in U . S . and Turkish Kindergarten thru 12 th Grade Public School System: A Comparative Study. International Journal of Teaching and Education, II(2), 10-20.

Fujii, T. (2016). Designing and adapting tasks in lesson planning: a critical process of Lesson Study. ZDM, 48(4), 411-423. https:// doi.org/10.1007/s11858-016-0770-3

Gunawan, I. (2017). Indonesian Curriculum 2013 : Instructional Management, Obstacles Faced by Teachers in Implementation and the Way Forward. In Advances in Social Science, Education and Humanities Research (Vol. 128, hal. 56-63). Atlantis Press. https://doi.org/10.2991/icet-17.2017.9 
Jurgelaitis, M., Ceponiene, L., \& Drungilas, V. (2018). Using Gamification for Teaching UML in Information System Design Course. CEUR-WS, 2145, 88-94.

Kaleb, B. J., Lengkong, V. P. ., \& Taroreh, R. N. (2019). Penerapan Sistem Informasi Manajemen dan Pengawasannya di Kantor Pelayanan Pajak KPP Pratama Manado. Jurnal EMBA, 7(1), 781-790.

Koloay, L. P., Morasa, J., \& Elim, I. (2014). Peranan Sistem Informasi Akuntansi dalam Efektifitas Pelaporan Informasi Akuntansi Pertanggungjawaban Pada PT. POS Indonesia (Persero) Manado, 2(2), 1528-1538.

Kornelis, M., \& Ock, Y. S. (2014). Design of School Management Information System Based on the Indonesian National Education Standard. International Journal of Contents, 10(2), 67-73. https://doi.org/10.5392/IJoC.2014.10.2.067

Luzi, D., Pecoraro, F., \& Tamburis, O. (2016). Integrating a conceptual representation of business model with UML.

Machmud, R. (2013). Peranan penerapan sistem informasi manajemen terhadap efektivitas kerja pagawai lembaga pemasyarakatan narkotika (lapastika) bollangi kabupaten gowa. Jurnal Capacity STIE AMKOP, 9(3), 409-421.

Machmuddah, Z., \& Suhartono, E. (2019). Peranan Aplikasi Sistem BOP PAUD yang Akuntabel untuk Guru PAUD Kota Semarang The Role of BOP PAUD System Aplication Accountable for PAUD Teachers in Semarang City. Abdimasku: Jurnal Pengabdian Masyarakat, 2(2), 114-120. https://doi.org/10.33633/ja.v2i2.45

Meliana, Julianto, V., \& Hafidz, K. A. (2020). Sistem Informasi Manajemen Taman Kanak-Kanak (Studi Kasus: Taman Kanak-Kanak (TK) Mekar Sari Desa Ambawang). Aisyah Journal of Informatics and Electrical Engineering, 2(2), 145-151. https:// doi.org/10.30604/iti.v2i2.39

Noviawati, N. (2017). The Implementation of 2013 Curriculum in English TEching Learning at MAN 1 Pekalongan. Indonesian Journal of English Teaching, 6(2), 218-228. https:// doi.org/10.15642/ijet2.2017.6.2.218-228

Nugroho, Y. S. (2015). Pengembangan Manajemen Data Elektronik PAUD di PAC Aisyiyah Kecamatan Tingkir, Salatiga. Warta LPM, 18(2), 110-117. https://doi.org/10.23917/warta.v18i2.1950

Oliva, P. F. (2005). Developing the Curriculum. Allyn and Bacon.

Parsaorantua, P. H., Pasoreh, Y., \& Rondonuwu, S. A. (2017). Implementasi Teknologi Informasi dan Komunikasi (Studi tentang Web E-Government di Kominfo Kota Manado). Acta Diurna Komunikasi, VI(3), 1-14.

Piper, B., Sitabkhan, Y., Mejía, J., \& Betts, K. (2018). Effectiveness of Global South : Scripting , Learning Outcomes, and Classroom Utilization. https://doi.org/10.3768/rtipress.2018.op.0053.1805

Prananda, A. A., \& Datu, C. (2016). Peranan Sistem Informasi Akuntasi Manajemen dalam Pengambilan Keputusan Investasi Asset Tetap pada PT. ETMIECO Sarana Laut Bitung. Jurnal EMBA, 4(1), 1531-1541. https://doi.org/10.35794/emba.v4i1.12375

Prasetyo, Z. K. (2011). Pengembangan Perangkat Pembelajaran Sains Terpadu untuk Meningkatkan Kognitif, Keterampilan Proses, Kreativitas serta Menerapkan Konsep Ilmiah Peserta Didik SMPNo Title. Yogyakarta.

Rohita. (2020). The Ability of Ece Teachers To Use ICT in The Industrial Revolution 4.0. Jurnal Obses, 4(2), 502-511. https://doi.org/10.31004/obsesi.v4i2.339

Rohita, Fitria, N., \& Haryadi, D. (2018). Pemanfaatan Aplikasi Penyusunan Perencanaan Pembelajaran (AP3) dalam Penyusunan Perencanaan Pembelajaran bagi Guru Taman Kanak-kanak di Jakarta. Jurnal Pengabdian kepada Masyarakat, 24(2), 644-654. https:// doi.org/10.24114/jpkm.v24i2.10168

Sujoko. (2013). Pemanfaatan Teknologi Informasi dan Komunikasi sebagai Media Pembelajaran di SMP Negeri 1 Geger Madiun. Jurnal Kebijakan dan Pengembangan Pendidikan, 1(1), 71-76. https://doi.org/10.22219/jkpp.v1i1.1511

Terolli, E., \& Hakrama, I. (2014). Modeling a Career Office Information System with UML. In ISCIM (hal. 102-105). Tirana.

Wazlawick, \& Sidnei, R. (2014). Object-Oriented Analysis and Design for Information Systems. (A. Dierna, Ed.). USA: Elsevier.

Yusnida, D., Muslem, A., \& Manan, A. (2017). A Study of Teaching Listening. English Education Journal, $8(4), 439-456$. 